\title{
Radioimmunoscintigraphy and immunohistochemistry with melanoma-associated monoclonal antibodies in choroidal melanoma: a comparison of the clinical and immunohistochemical results
}

\author{
D F Schaling, J P van der Pol, M J Jager, M J P G van Kroonenburgh, J A Oosterhuis, D J \\ Ruiter
}

\begin{abstract}
Radioimmunoscintigraphy with monoclonal antibodies (MoAbs) to melanoma associated antigens is a new technique that can be used as an additional test to detect ocular melanomas in clinically difficult cases. Immunoscintigraphy with ${ }^{99 m}$ technetium-labelled monoclonal antibody fragments of MoAb 225.28S in 14 patients with melanoma yielded a positive image in only six cases (43\%). The expression of high molecular weight melanoma-associated antigen (HMW-MAA) was immunohistochemically assessed in melanoma tissue obtained from these 14 patients to find a possible correlation between the results of immunoscintigraphy and expression of the HMW-MAA. The melanoma tissues were immunohistochemically stained by a sensitive immunoperoxidase procedure with three different monoclonal antibodies to the HMWMAA: 225.28S, Mel-14, and AMF-6. Expression of the antigen detected by MoAb 225.28S was found in 13 of 14 melanomas; the MoAbMel-14 reacted positively with all 14 melanomas; staining with MoAb AMF-6 was achieved in 10 melanomas. No correlation was found between the immunohistochemical staining results, the conventional histopathological findings, and the immunoscintigraphic results. The immunohistochemical staining results suggest that anti-HMW-MAA MoAbs bind to the melanoma tissue and are therefore potentially suitable for immunoscintigraphy.
\end{abstract}

Since the development of the hybridoma technology ${ }^{1}$ several monoclonal antibodies (MoAbs) have been raised against cutaneous melanoma. ${ }^{2-9}$ Only a few MoAbs have been developed against uveal melanoma. ${ }^{10} \mathrm{~A}$ major reason for the limited number of antibodies to uveal melanoma is the problem of establishing a uveal melanoma cell line which facilitates the induction and characterisation of uveal melanoma specific MoAbs. Fortunately several MoAbs of cutaneous melanoma show cross reactivity with uveal melanoma tissue..$^{11-13}$

Antibodies such as $225 \cdot 28 \mathrm{~S}$ are directed to a high molecular weight melanoma-associated antigen (HMW-MAA), ${ }^{3}$ which is expressed in about $90 \%$ of the cutaneous melanomas. ${ }^{14}$ is Expression of the HMW-MAA in uveal melanoma was found to occur in 40 to $50 \%$ of cases. ${ }^{1216}$

The ${ }^{99 m}$ technetium-labelled antibody $225 \cdot 28 \mathrm{~S}$ has been used for immunoscintigraphy in uveal melanoma patients and yielded detection percentages from $37 \%$ to $64 \% .{ }^{17-19}$ The use of sophisticated equipment like single photon emission computerised tomography (SPECT) or a 'double pinhole' collimator enhanced the detection percentages to $73 \%$ to $92 \% .^{17-19}$ In view of the results of the relatively low in-situ expression of the HMW-MAA in uveal melanoma in previous studies ${ }^{1216}$ the detection rates of immunoscintigraphy with $\mathrm{MoAb}$ $225 \cdot 28 \mathrm{~S}$ in patients seem to be surprisingly high. Since we could obtain tumour tissue from 14 patients who participated in a previous immunoscintigraphic study with MoAb $225 \cdot 28 \mathrm{~S}^{19}$ we determined the expression of the HMW-MAA immunohistochemically in these tissues. In addition to monoclonal antibody $225 \cdot 28 \mathrm{~S}$ to the HMW-MAA, MoAb Mel-14 ${ }^{2}$ and MoAb AMF$6^{20}$ were used for immunohistochemical analysis.

\section{Patients and methods}

IMMUNOSCINTIGRAPHY

Radioimmunoscintigraphy was performed in 14 melanoma patients with MoAb 225.28S from an instant labelling kit (Technemab-K-1; Sorin Biomedica, Italy). For immunoscintigraphy 250-350 $\mu \mathrm{g}$ of antibody labelled with $740 \mathrm{MBq}$ ${ }^{99 \mathrm{~m}}$-technetium was administered by means of a slow intraveous injection. For more detailed information on the immunoscintigraphy we refer to a previous publication. ${ }^{19}$

\section{HISTOPATHOLOGY}

Specimens of uveal melanomas from the same 14 patients were obtained after enucleation of the eye. The enucleations were performed at the Leiden University Hospital or at the Academic Medical Centre of Amsterdam. A portion of each specimen was snap-frozen and stored at $-20^{\circ} \mathrm{C}$ for immunohistochemical analysis. The remainder of each tumour was processed for conventional histopathological examination.

The histopathological diagnosis was assessed on paraffin and/or celloidin sections. Cell type was recorded as spindle cell, epithelioid cell, or 
mixed cell type. Pigmentation was scored as absent, less than half of the cells pigmented, more than half of the cells pigmented, or heavily pigmented. In addition invasion was scored as absent, slight (less than $25 \%$ of the scleral thickness), moderate (approximately 50\%), deep (approximately $75 \%$ ), or episcleral.

\section{IMMUNOPEROXIDASE STUDY}

Frozen sections $4 \mu \mathrm{m}$ thick were air dried and fixed in acetone for $10 \mathrm{~min} .{ }^{20}$ Sections were incubated for $60 \mathrm{~min}$ at room temperature with MoAb diluted in phosphate buffered saline and then for $30 \mathrm{~min}$ with rabbit-mouse immunoglobulin-horse-radish peroxidase conjugate (Tago, Sanbio BV, Uden, The Netherlands). Between the two incubations the sections were washed three times with phosphate buffered saline $(\mathrm{pH} 7 \cdot 4)$. Staining was achieved by incubation of sections for $10 \mathrm{~min}$ in an acetate buffer solution ( $\mathrm{pH} 5.0$ ) that contained 3-amino9-ethyl-carbazole (AEC). Alternatively staining was performed by incubation of sections in a phosphate imidazole buffer solution ( $\mathrm{pH} \mathrm{7 \cdot 6)}$ that contained diamino-benzidine (DAB). Finally, the sections were washed, counterstained in Mayer's haematoxylin, and mounted in Aquamount (Gurr, BDH Chemicals Ltd, Poole, England). As a negative control a section was incubated with irrelevant MoAbs instead of anti-HMW-MAA MoAbs as the first step. Sections of cutaneous melanoma were used as positive controls.

The results of both the AEC and DAB staining methods were compared. The percentage of stained tumour cells was estimated independently by two observers. Differences in results between the observers were less than $10 \%$. In addition the intensity of cellular staining was assessed. Correlations between expression of different antigens were assessed by the Kendall rank correlation procedure. The results of the two staining methods were analysed by Wilcoxon's paired signed ranks test.

\section{MONOCLONAL ANTIBODIES}

The MoAb $225 \cdot 28 \mathrm{~S}$ was tested in the form provided as a ready-to-use kit for clinical use by Sorin Biomedica, and in the pure form as provided by Dr S Ferrone. Prior to immunohistochemistry with MoAb $225 \cdot 28 \mathrm{~S}$ from the ready-to-use kit ion exchange chromatography by means of a DEAE-Sephadex A25 column was performed. This procedure is routinely performed after labelling the antibody with $\mathrm{tc}^{99 \mathrm{~m}_{-}}$ pertechnetate for immunoscintigraphy to reduce the amount of free pertechnetate. Ion exchange chromatography was performed to check its influence on the antibody's immunoreactivity. The two batches of antibody $225 \cdot 28 \mathrm{~S}$ were compared by Wilcoxon's paired signed ranks test. Two other antibodies, Mel-14 and AMF-6 to high molecular weight melanoma-associated antigen were obtained from Dr S Carrel and Dr C Figdor.

\section{Results}

The results of immunohistochemistry, immunoscintigraphy (planar scintigraphy), and histology are summarised in Table I. With planar scintigraphy six of 14 melanomas could be visualised. On immunohistochemistry (diamino-benzidine staining with $225 \cdot 28 \mathrm{~S}$ antibody from the readyto-use kit) 13 of 14 melanomas (92\%) showed expression of the antigen to which MoAb $225 \cdot 28 \mathrm{~S}$ is directed. Immunohistochemistry with the pure antibody $225 \cdot 28 \mathrm{~S}$ showed expression of the HMW-MAA in 12 of 14 melanomas. The numbers of positively staining cells with the two batches of antibody $225 \cdot 28 \mathrm{~S}$ did not differ significantly (Wilcoxon's paired signed ranks test, $p=0 \cdot 00033$ ). Expression of the antigens detected by the MoAb Mel-14 and AMF-6 was found in 14 and 10 melanomas, respectively.

The Kendall rank correlation procedure was used to assess a possible correlation between 'detection on planar scintigraphy' and the following parameters: tumour prominence, pigmentation, cell type, expression of MoAb $225 \cdot 28 \mathrm{~S}$ in cells, expression of MoAb $225 \cdot 28 \mathrm{~S}$ in vessels, expression of Mel-14 cells, and expression of AMF- 6 cells. No correlation between any of these parameters and detection on scintigraphy was found. The expression of MoAb 225.28S was positively correlated with the expression of Mel-14 (14 observations, Kendall rank correlation procedure, $\mathrm{p}=0.037$ ). The expression of AMF- 6 was not correlated to the expression of either Mel-14 or $225 \cdot 28 \mathrm{~S}$ (14 observations).

Table 1 Immunohistochemistry, scintigraphy and histology

\begin{tabular}{|c|c|c|c|c|c|c|c|c|c|c|c|c|c|c|c|c|c|}
\hline \multirow[t]{2}{*}{ Patient } & \multirow[t]{2}{*}{$\begin{array}{l}\text { Sex/ } \\
\text { age }\end{array}$} & \multicolumn{2}{|c|}{$\begin{array}{l}D A B \\
\text { staining } \\
\text { (Ferrone) } \\
225 \cdot 28 S\end{array}$} & \multicolumn{3}{|c|}{$\begin{array}{l}D A B \\
\text { staining } \\
\text { (Sorin) } \\
225 \cdot 28 S\end{array}$} & \multicolumn{2}{|c|}{$\begin{array}{l}\text { AEC } \\
\text { staining } \\
225 \cdot 28 S \\
\text { (Ferrone) }\end{array}$} & \multicolumn{2}{|c|}{$\begin{array}{l}\text { DAB } \\
\text { staining } \\
\text { Mel } \cdot 14\end{array}$} & \multicolumn{2}{|c|}{$\begin{array}{l}D A B \\
\text { staining } \\
A M F \cdot 6\end{array}$} & \multirow[t]{2}{*}{$\begin{array}{l}\text { Scintigraphy } \\
\text { graphy }\end{array}$} & \multirow[t]{2}{*}{$\begin{array}{l}\text { Tumour } \\
\text { prominence } \\
(\mathrm{mm})\end{array}$} & \multirow[t]{2}{*}{$\begin{array}{l}\text { Cell } \\
\text { type }\end{array}$} & \multirow[t]{2}{*}{$\begin{array}{l}\text { Pigmen- } \\
\text { tation }\end{array}$} & \multirow[t]{2}{*}{$\begin{array}{l}\text { Scleral } \\
\text { invasion }\end{array}$} \\
\hline & & $\star$ & $t$ & $\star$ & $t$ & $\ddagger$ & $\star$ & $t$ & * & $\dagger$ & $\star$ & $t$ & & & & & \\
\hline $\begin{array}{r}1 \\
2 \\
3 \\
4 \\
5 \\
6 \\
7 \\
8 \\
9 \\
10 \\
11 \\
12 \\
13 \\
14\end{array}$ & $\begin{array}{l}F / 58 \\
M / 75 \\
F / 65 \\
M / 42 \\
M / 65 \\
M / 76 \\
F / 56 \\
M / 76 \\
M / 68 \\
M / 65 \\
M / 75 \\
F / 64 \\
F / 65 \\
F / 69\end{array}$ & $\begin{array}{r}80 \\
100 \\
90 \\
80 \\
90 \\
0 \\
100 \\
90 \\
60 \\
70 \\
70 \\
80 \\
100 \\
0\end{array}$ & $\begin{array}{l}1 \\
1 \\
1 \\
1 \\
2 \\
-1 \\
1 \\
1 \\
1 \\
1 \\
1 \\
1 \\
2 \\
-\end{array}$ & $\begin{array}{r}30 \\
100 \\
10 \\
50 \\
80 \\
5 \\
100 \\
100 \\
40 \\
75 \\
80 \\
80 \\
100 \\
0\end{array}$ & $\begin{array}{l}1 \\
1 \\
1 \\
1 \\
3 \\
1 \\
2 \\
2 \\
1 \\
1 \\
1 \\
2 \\
2 \\
-\end{array}$ & $\begin{array}{l}1 \\
\overline{2} \\
0 \\
2 \\
2 \\
2 \\
2 \\
3 \\
\overline{2} \\
2 \\
2 \\
1\end{array}$ & $\begin{array}{r}50 \\
10 \\
80 \\
40 \\
50 \\
5 \\
5 \\
40 \\
50 \\
0 \\
30 \\
40 \\
70 \\
0\end{array}$ & $\begin{array}{l}1 \\
1 \\
2 \\
1 \\
1 \\
1 \\
1 \\
1 \\
1 \\
-1 \\
1 \\
1 \\
1 \\
-\end{array}$ & $\begin{array}{r}100 \\
100 \\
20 \\
25 \\
100 \\
20 \\
100 \\
100 \\
100 \\
90 \\
100 \\
100 \\
100 \\
100\end{array}$ & $\begin{array}{l}2 \\
2 \\
2 \\
1 \\
2 \\
1 \\
2 \\
2 \\
1 \\
2 \\
1 \\
1 \\
2 \\
1\end{array}$ & $\begin{array}{r}100 \\
30 \\
0 \\
0 \\
10 \\
0 \\
10 \\
20 \\
20 \\
70 \\
10 \\
10 \\
80 \\
0\end{array}$ & $\begin{array}{l}2 \\
1 \\
- \\
- \\
1 \\
-1 \\
1 \\
1 \\
1 \\
1 \\
1 \\
1 \\
-\end{array}$ & $\begin{array}{l}\text { Neg } \\
\text { Neg } \\
\text { Pos } \\
\text { Pos } \\
\text { Pos } \\
\text { Neg } \\
\text { Neg } \\
\text { Pos } \\
\text { Neg } \\
\text { Neg } \\
\text { Neg } \\
\text { Pos } \\
\text { Neg } \\
\text { Pos }\end{array}$ & $\begin{array}{c}5 \cdot 5 \\
2 \cdot 2 \\
15 \\
3 \\
7 \cdot 9 \\
10 \\
9 \cdot 5 \\
15 \\
11 \\
8 \\
3 \cdot 5 \\
7 \cdot 5 \\
4 \cdot 9 \\
6\end{array}$ & $\begin{array}{l}\text { Spindle } \\
\text { Spindle } \\
\text { Mixed } \\
\text { Mixed } \\
\text { Epithel } \\
\text { Epithel } \\
\text { Mixed } \\
\text { Mixed } \\
\text { Mixed } \\
\text { Spindle } \\
\text { Mixed } \\
\text { Mixed } \\
\text { Mixed } \\
\text { Mixed }\end{array}$ & $\begin{array}{l}1 \\
2 \\
1 \\
0 \\
2 \\
1 \\
1 \\
1 \\
2 \\
3 \\
3 \\
2 \\
2 \\
1\end{array}$ & $\begin{array}{l}\text { Moderate } \\
\text { Slight } \\
\text { \$ } \\
\text { Deep } \\
\text { Episcleral } \\
\text { Slight } \\
\text { Absent } \\
\text { Slight } \\
\text { Episcleral } \\
\text { Deep } \\
\text { Episcleral } \\
\text { Episcleral } \\
\text { Slight } \\
\text { Moderate }\end{array}$ \\
\hline
\end{tabular}

*Percentage of positively staining cells. $\nmid$ Intensity of staining $(1=$ weak, $2=$ moderate, $3=$ strong $)$ $\ddagger$ Intensity of vessel staining $(1=$ weak, $2=$ moderate, $3=$ strong, $-=$ not assessable, owing to heavy pigmentation or cell staining. SCould not be determined owing to preparational artefact. 
Staining of the tumour vasculature with $\mathrm{MoAb}$ $225 \cdot 28 \mathrm{~S}$ was found in 11 out of 14 cases. In two cases staining of the vessels could not be determined owing to heavy pigmentation of the tumour or diffuse cellular staining with the MoAb.

\section{Discussion}

The expression of the antigen detected by MoAb $225 \cdot 28 \mathrm{~S}$ in 13 out of 14 melanomas $(92 \%)$ in the immunohistochemical study is in agreement with the results of one study (83\% expression), ${ }^{13}$ but two other studies showed a much lower expression of the antigen in uveal melanomas (50\% and $41 \%$ expression respectively). ${ }^{12} 16$ The percentage of positively staining cells per tumour is also higher in the present study than in a previous study. ${ }^{12}$ A major reason for the difference between the results of this study and of the previous study ${ }^{12}$ may be the use of diaminobenzidine staining in the present study, which proved to be much more sensitive than 3-amino9-ethyl-carbazole. The results of this study indicate that the antibody $225 \cdot 28 \mathrm{~S}$ may be useful in immunoscintigraphic diagnosis of uveal melanoma, whereas previous studies showed only a limited expression of the HMW-MAA in uveal melanoma. ${ }^{12-16}$

The expression of the HMW-MAA in choroidal and cutaneous melanoma vessels has been previously shown with use of the 225-28S antibody. ${ }^{121}$ An immunoelectron microscopic study revealed that the HMW-MAA is located in the mural pericytes surrounding the endothelial cells. ${ }^{21}$

The expression of antigen detected by Mel-14 in this study is in agreement with a previous study. ${ }^{2}$ The expression of Mel-14 was correlated with the expression of the antigen detected by 225.28S (Kendall rank correlation procedure, $\mathrm{p}=0.037$ ). The high antigen expression makes the Mel-14 antibody suitable for immunodiagnosis.

Expression of the antigen detected by AMF-6, which is at present called NKI-M6, was higher than the expression previously found. ${ }^{22}$

No correlation was found between tumour detection on scintigraphy with MoAb $225 \cdot 28 \mathrm{~S}$ and antigen expression for MoAb $225 \cdot 28 \mathrm{~S}$. Such a correlation was previously found in cutaneous melanoma. ${ }^{23}$ Since we observed expression of the HMW-MAA in this study in $92 \%$ of the cases, the detection of six of 14 melanomas by planar scintigraphy with labelled MoAb $225 \cdot 28 \mathrm{~S}$ is low. In one melanoma which could be imaged by planar scintigraphy and SPECT no expression of HMW-MAA was seen immunohistochemically (Table I). Heterogenous expression of HMWMAA in the tumour may explain this difference. ${ }^{12}$ On the other hand the expression of HMW-MAA in the tumour vessels may have been responsible for the positive image. Local factors such as vascular perfusion, necrosis, or the presence of an inflammatory infiltrate may influence adequate uptake of antibody in vivo. Necrosis or inflammatory infiltrate was scarcely present in our material.

Scintigraphy results of another study showed a higher detection rate with MoAb 225.28S. An explanation for this difference may be the performance of three scans after injection of the antibody ${ }^{24}$ as compared with one scan in our study. ${ }^{19}$ Performance of several scans at standard consecutive time intervals may provide information on the distribution of activity in the course of time. A specific activity in the vessels is high directly after injection of the antibody and then decreases, while a specific binding of antibody to the antigen needs some time to become established, and specific tracer uptake will increase on the consecutive images.

An important limiting factor is the high nonspecific background activity in the nasopharyngeal region, but the use of single photon emission computerised tomography enables the physician adequately to differentiate the tumour from the nasopharyngeal activity. ${ }^{1824}$

The results of the present study indicate that with a sensitive immunoperoxidase procedure the MoAbs $225 \cdot 28 \mathrm{~S}$ and Mel-14 show adequate binding in uveal melanoma tissue. The immunochemical study supports the results of some clinical studies indicating the usefulness of antibody $225 \cdot 28 \mathrm{~S}$ for immunodiagnostic procedures in uveal melanoma. ${ }^{17}{ }^{18}$ However in view of our clinical results as well as recent correspondence in this journal ${ }^{25}$ the conditions of adequate immunoscintigraphy have to be carefully assessed.

A part of this study was presented at the International Symposium on Tumours of the Eye in Essen, West Germany, on 21-2 September 1989, organised by the German Ophthalmologica Society (Deutsche Ophthalmologische Gesellschaft)

The authors thank Drs S Ferrone, New York Medical College, Valhalla, New York, S Carrel, Ludwig Institute for Cancer Research, Epalinges-sur-Lausanne, Switzerland, and C Figdor, The Netherlands Cancer Institute, Amsterdam, for kindly providing monoclonal antibodies $225 \cdot 28 \mathrm{~S}$, Mel-14 and AMF-6, provectively. We Mectical Medical Statistics, University Medical Centre Leiden for statistical computations, Mr F Kwaspen, Institute of Pathology,
University Hospital Nijmegen, for technical assistance, and Mrs Wniversity Hospital Nijmegen, for

1 Kohler G, Milstein C. Continuous cultures of fused cells secreting antibody of predefined specifity. Nature 1975; 256 : 495-7.

2 Carrel S, Accolla RS, Carmagnole AL, Mach JP. Common human melanoma associated antigens detected by monoclonal antibodies. Cancer Res 1980; 40: 2523-8.

3 Imai K, Molinaro GA, Ferrone S. Monoclonal antibodies to human melanoma associated antigens. Transplant Proc 1980 12: $380-3$

4 Steplewski Z, Herlyn M, Herlyn D, Clark W, Koprowski H Reactivity of monoclonal anti-melanoma antibodies with melanoma cells freshly isolated from primary and metastatic melanoma. Eur F Immunol 1979; 9: 94-6.

5 Hellström IH, Garrigues J, Cabasco L, Mosely GH, Brown JP, Hellström KE. Studies of a high molecular weight human melanoma-associated antigen. $\mathcal{F}$ Immunol 1983; 130: 146772 .

6 Bumol TF, Reisfeld RA. Unique glycoprotein-proteoglycan complex defined by monoclonal antibody on human mela complex defined by monoclonal antibody on human mat
noma cells. Proc Natl Acad Sci USA1982; 79; 1245-9.

7 Brown JP, Woodbury RG, Hart CE, Hellström KE. Quantitative analysis of melanoma-associated antigen $\mathrm{p} 97$ in norma and neoplastic tissues. Proc Natl Acad Sci USA 1981; 78: $539-43$

8 Dippold WG, Lloyd KO, Li LTL, Ikeda H, Oettgen HF, Old LJ. Cell surface antigens of human malignant melanoma: definition of six antigenic systems with mouse monoclonal antibodies. Proc Natl Acad Sci USA 1980; 77 6114-8.

9 Imai K, Natali PG, Kay NE, Wilson BS, Ferrone S. Tissue distribution and molecular profile of a differentiation antigen detected by a monoclonal antibody $(345 \cdot 134 \mathrm{~S})$ produced against human melanoma cells. Cancer Immunol Immunother 1982; 12: 159-66.

10 Damato BE, Campbell AM, McGuire BJ, Lee WR, Foulds WS. Monoclonal antibodies to human primary uveal melanomas demonstrate tumor heterogeneity. Invest melanomas demonstrate tumor

11 Folberg R, Donoso LA, Atkinson BF, Ernst CS, Herlyn M Arbizzon VV. An antimelanoma monoclonal antibody and the histopathology of uveal melanomas. Arch Ophthalmol 1985; 103: 275-9. 
12 Van der Pol JP, Jager MJ, de Wolff-Rouendaal D, Ringens PJ, Vennegoor C, Ruiter DJ. Heterogenous expression of melanoma-associated antigens in uveal melanomas. Curr Eye Res 1987; 6: 757-65.

13 Bomanji J, Garner A, Prasad J, et al. Characterisation of ocular melanoma with cutaneous melanoma antibodies. $\mathrm{Br} \mathcal{J}$

14 Wilson BS, Imai K, Natali PG, Ferrone S. Distribution and molecular characterization of a cell-surface and a cytoplasmic antigen detectable in human melanoma cells with monoclonal antibodies. Int $f$ Cancer 1981; 28: 293-300.

15 Natali PG, Bigotti A, Cavaliere R, Nicotra MR, Ferrone S. Phenotyping of lesions of melanocyte origin with monoclonal Phenotyping of lesions of melanocyte origin with monoclonal antibodies to melanoma-associated antigens

16 Natali PG, Bigotti A, Nicotra MR, et al. Analysis of the antigenic profile of uveal melanoma lesions with anticutaneous melanoma-associated antigen and anti-HLA monoclonal antibodies. Cancer Res 1989; 49: 1269-74.

17 Bomanji J, Hungerford JL, Granowska M, Britton KE. Radioimmunoscintigraphy of ocular melanoma with ${ }^{2 m} \mathrm{~T}$ labelled cutaneous melanoma antibody fragments. $\mathrm{Br} \mathcal{F}$ Ophthalmol 1987; 71: 651-8.

18 Scheidauer K, Markl A, Leinsinger G, et al. Immunoscintigraphy in intraocular malignant melanoma. Nucl Med Scintigraphy in intraocula
19 Schaling DF, Van Kroonenburg MJPG, Borsje RA, et al. Radioimmunoscintigraphy with melanoma associated monoclonal antibody fragments in ocular melanoma. Graefes Arch Clin Exp Ophthalmol 1989; 227: 291-4.

20 Ruiter DJ, Bergman W, Welvaart K, et al. Immunohistochemical analysis of malignant melanomas and nevocellular nevi with monoclonal antibodies to distinct monomorphic determinants of HLA antigens. Cancer Res $1984 ; 44: 3930-5$.

21 Schlingemann RO, Rietveld FJR, De Waal RMW, Ferrone S, Ruiter DJ. Does the melanoma-associated high-molecularweight antign weight antigen play a role in pericyte function during t
angiogenesis? Proc Am Assoc Cancer Res 1989; 30: 378 .

22 Ringens PJ, Van Haperen R, Vennegoor C, et al. Monoclonal antibodies in detection of choroidal melanoma. Grefels Arch Clin Exp Ophthalmol 1989; 227: 287-90.

23 Siccardi AG, Buraggi GL, Callegaro L, et al. Multicenter study of immunoscintigraphy with radiolabelled monoclonal antibodies in patients with melanoma. Cancer Res 1986; 46: 4817-22.

24 Bomanji J, Nimmon CC, Hungerford JL, Solanski K Granowska M, Britton KE. Ocular radioimmunoscintigraphy: sensitivity and practical considerations. $\mathcal{F} \mathrm{Nucl} \mathrm{Med}$ 1988; 29: 1038-44.

25 Tullo AB, Dodd CJ, Noble JL, Owens S, Rao H. Correspondence on ocular melanoma. Br $\mathcal{F}$ Ophthalmol 1989; 73: 771. Hungerford J: In reply. Br f Ophthalmol 1989; 73: 7712 . 